\title{
Correction to: Assessing the belt and road initiative as a narrative: Implications for institutional change and international firm strategy
}

\author{
Tomas Casas-Klett ${ }^{1}$ Jiatao $\mathrm{Li}^{2}$ (1) \\ Published online: 17 April 2021 \\ (c) The Author(s) 2021, corrected publication 2021
}

\section{Correction to: Asia Pacific Journal of Management https://doi.org/10.1007/s10490-021-09757-x}

The original version of this article unfortunately contained mistakes.

1. Casas was incorrectly captured as given name. It should be: Tomas as given name and Casas-Klett as last name.

2. The correct address of Jiatao Li's affiliation should be: Clear Water Bay, Hong Kong.

3. Below is the correct author biography of Tomas Casas-Klett:

Tomas Casas-Klett (PhD, University of St. Gallen, Switzerland) is Assistant Professor at the University of St. Gallen's Research Institute for International Management (FIM-HSG), and Director of the China Competence Center. His research interests include elite value creation business models and the global elite quality index (EQx), free-trade agreements (FTAs), top team performance, narrative economics, and Asian entrepreneurship and innovation models.

4. The article "Assessing the belt and road initiative as a narrative: Implications for institutional change and international firm strategy", written by Tomas Casas-Klett and Jiatao Li, was originally published electronically on the publisher's internet portal on 07 March 2021 without open access. With the author(s)' decision to opt for Open Choice the copyright of the article changed on 30 April 2021 to (C) The

The original article can be found online at https://doi.org/10.1007/s10490-021-09757-x.

Jiatao Li

mnjtli@ust.hk

Tomas Casas-Klett

tomas.casasiklett@unisg.ch

1 University of St. Gallen, St. Gallen, Switzerland

2 Department of Management, Hong Kong University of Science and Technology,

Clear Water Bay, Hong Kong 
Author(s) 2021 and the article is forthwith distributed under a Creative Commons Attribution 4.0 International License, which permits use, sharing, adaptation, distribution and reproduction in any medium or format, as long as you give appropriate credit to the original author(s) and the source, provide a link to the Creative Commons licence, and indicate if changes were made. The images or other third party material in this article are included in the article's Creative Commons licence, unless indicated otherwise in a credit line to the material. If material is not included in the article's Creative Commons licence and your intended use is not permitted by statutory regulation or exceeds the permitted use, you will need to obtain permission directly from the copyright holder. To view a copy of this licence, visit http:// creativecommons.org/licenses/by/4.0.

The original article has been corrected.

Open Access This article is licensed under a Creative Commons Attribution 4.0 International License, which permits use, sharing, adaptation, distribution and reproduction in any medium or format, as long as you give appropriate credit to the original author(s) and the source, provide a link to the Creative Commons licence, and indicate if changes were made. The images or other third party material in this article are included in the article's Creative Commons licence, unless indicated otherwise in a credit line to the material. If material is not included in the article's Creative Commons licence and your intended use is not permitted by statutory regulation or exceeds the permitted use, you will need to obtain permission directly from the copyright holder. To view a copy of this licence, visit http://creativecommons.org/licen ses/by/4.0/.

Publisher's Note Springer Nature remains neutral with regard to jurisdictional claims in published maps and institutional affiliations. 